\title{
STUDIES OF THE DIET OF STUDENTS AT EDINBURGH UNIVERSITY
}

\author{
BY \\ A. H. KITCHIN, R. PASSMORE, M. PYKE, and G. M. WARNOCK \\ From the Department of Public Health and Social Medicine, Edinburgh University, and the Scientific $\vec{D}_{-}$ \\ Adviser's Division of the Ministry of Food
}

Introduction
Scope
Technique
Results
Average daily consumption of nutrients
Consumption of individual foodstuffs
Pattern of food habits

Discussion and conclusions

\section{INTRODUCTION}

Sir John Boyd Orr (1937) demonstrated that in the social and economic conditions prevailing in Great Britain during the nineteen-thirties one-tenth of the population was consuming food which was both insufficient in quantity and unsatisfactory in quality when compared with accepted dietary standards. This underfeeding was associated with much ill health and poor physical development. The outbreak of the 1939-45 war stimulated the Government into a large number of measures designed to control the distribution of food equitably and thereby to raise the level of health and the martial efficiency of the people. In this the Government appeared to achieve a great success, and the consensus of public opinion was that the limited food resources available throughout the period of the war were shared out equitably in relation to human needs. Further, the majority of expert opinion agreed that not only had the general health of the people not deteriorated as a result of the food restrictions, but in certain respects, notably as regards infant and maternal health, an improvement had taken place. Rationing, with its inconveniences and irksome restrictions, was accepted as inevitable while hostilities lasted. Many persons had, however, fostered the false hope that, with the cessation of fighting in 1945, food restrictions, too, would soon cease. But few people had realized the precarious position of international agriculture, even before the outbreak of hostilities, and the serious blows it received during the war. The damage to world trading also precluded any possibilities of an immediate, plenteous supply of: food capable of meeting all demands. Indeed, in $\overrightarrow{0}$ 1946-47 and in early 1948 the food situation in this? country deteriorated. A "dollar crisis" in theautumn of 1947 and a partial failure of our potatoc crop combined to make that winter perhaps the worst from a food point of view since 1939. It has now indeed become clear to almost all of us that food shortages are likely to persist for a long period and that restrictions are a feature of peace as well as of war.

Now, rationing is no longer a military emergency measure and a complex governmental food-control-o ling machine has become a recognized part of peacetime economy. It is therefore important to $\stackrel{\unrhd}{\mathbb{2}}$ devise means to study the machinery and its effect $\vec{F}$ on food consumption and food habits. Experiences 3 of other countries have shown that a rationing? scheme may be one thing on paper and a veryo different affair in practice. The present survey was undertaken to find out how a group of people were in fact faring during the winter 1947-48. University undergraduates enjoyed no special privileges as regards food. All the special rations for school-o children cease at the eighteenth birthday, before most of the students have entered the University ando also before many of the men have completed their growth and reached full stature. Further, universityo students who live at home or in lodgings do not receive the benefits of the numerous industrialo canteens available throughout the country to soN many young people. The study, then, is of a N group of people with no special privileged source of food supply.

\section{SCOPE OF THE SURVEY}

In all, 298 students took part in the survey and had their food consumption recorded. Only those $\frac{\text { ? }}{\oplus}$ students under 21 years were selected. With one $?$ or two exceptions none of them had undertaken $\varnothing$ 
military service. Thus the special problems presented by the large numbers of ex-service students were deliberately avoided and the sample selected as representative of young persons coming to the University straight from school. Table I shows the numbers of each and of their residence during term.

TABLE I

Number of Students SURVeyed

\begin{tabular}{cc|c|c|c}
\hline & & Men & Women & Total \\
\hline Living: & & 61 & 71 & 132 \\
$\begin{array}{c}\text { at home } \\
\text { in lodgings } \\
\text { hostels }\end{array}$ & $\ldots$ & 47 & 74 & 121 \\
\hline Total & $\ldots$ & 19 & 26 & 45 \\
\hline
\end{tabular}

Of this total, 145 were from the Arts faculty, 113 from Medicine, and 40 from Science. The Law and Divinity faculties contain only graduates proceeding to secondary degrees, so they were not included. No essential difference was found between the diets of the students in the different faculties, and no analyses on this basis have been recorded.

For the survey of students living at home or in lodgings, names were selected at random from matriculation rolls in the faculties of Arts and Medicine, and each selected individual was written to and asked to co-operate. Out of 126 selected medical students, 98 (78 per cent.) accepted and completed the survey. In Arts, 250 students were written to and 127 (51 per cent.) completed the survey. The numbers of those willing to take part in the survey were actually higher than these figures indicate. Unavoidable absenteeism prevented several students from co-operating. The 28 science students were all volunteers. The number of students in this faculty below the age of 21 was too small to allow any selection. The hostels chosen for this investigation were the two largest hostels for men and women respectively attached to the University. In the men's hostel there were 100 students_studying in all faculties of the University. On account of war service, many were older than usual, but 25 were below 21 years of age and of these, 19 completed the survey satisfactorily. The women students were chosen from a group of five hostels with common catering arrangements on the outskirts of Edinburgh, each with some 60 students. From these the names of 30 girls below 21 years were selected at random. These girls were asked to participate, and 26 concluded the survey.
The recordings took place at the end of the autumn and the beginning of the spring term, and covered the months of December, January, and February only. Each student was under continuous observation for eight consecutive days during this period.

\section{TECHNIQUe}

Many observers have produced reliable methods for the measurement of the food consumption of a whole family in the home. Weighing of all available food in the kitchen is the basis of these methods. Details of technique vary according to the socioeconomic level of the home, but accurate records of family food consumption in the home have been made in many countries throughout the world and in widely different social classes. Family surveys, based on observations in the kitchen, fail to record accurately the food derived from restaurants and canteens-a large and increasing proportion of the total food consumption in Great Britain today. Such surveys also can give no account of the distribution of the food within the family. To get accurate information on these points, nutrition workers have been developing methods of individual survey.

The accurate recording of the daily food intake of an individual is an exceedingly difficult task. The pioneers in this work were the classical experimental physiologists of the end of the nineteenth and beginning of the twentieth century. - For the metabolic measurements which they were making, precise records of food consumption were required, and for the most part "professional" subjects were used for the experiments. The difficulties of obtaining accurate dietary records are numerous and put a great strain on the honesty and good faith of the subject. Benedict (1919), a most experienced observer, preferred to choose the students of a religious foundation as his experimental subjects. Yet he asked them to promise in writing faithfully to weigh all they ate and took great pains in addition to obtain confessions of any items which they accidentally failed to record.

More recently, individual diet surveys have been made of larger groups in which each individual has been asked to weigh and measure every article of food immediately before consumption. Widdowson has been a pioneer in the use of this technique and records surveys of 63 middle-class men (Widdowson, and McCance, 1936), of 63 women, again nearly all from the middle class (Widdowson, 1936), and of 1,028 children (Widdowson, 1947). These and similar surveys have provided much valuable basic physiological knowledge. For sociologists and food 


\section{.}

administrators the technique has two limitations. First, only subjects who are willing, co-operative, and intelligent can be surveyed. Secondly, it is impossible to assess the changes in normal food habits and customs that may be brought about by the necessity of weighing all food before eating. The individual weighed survey may indeed give an accurate record of food consumption during the period of the survey, but this is not necessarily an accurate record of normal food consumption.

In an attempt to make the method more generally applicable with a minimum of loss of accuracy, some observers, notably Youmans and others (1942) and Bransby and Wagner (1945) have used ordinary domestic measures, such as cupfuls, spoonfuls, etc., instead of balances. Cups and spoons of a uniform size are provided, and sometimes models of foods with which the actual amounts eaten are compared. Bransby and others (1948) have shown that under certain circumstances these "homely measures" can be substituted for balances without any substantial loss of accuracy.

Some information about the nature and adequacy of a diet can be obtained by the collection of a simple diet history. This is essentially the method of practical clinical medicine. History-taking is a difficult art and suffers from the drawback that all data obtained are subjective in origin. Yet such data, if lacking the special precision of chemical measurements, may yet serve as useful guides to human behaviour. The "questionnaire " type of survey has the outstanding advantage that it involves a minimum of interference with the normal life of the subject. It can be used much more widely amongst the people than the weighed individual survey and, further, it is less likely to alter the usual dietary pattern. We have used this questionnaire method as being the only method, in our opinion, available for a survey of the extent we wanted. We have, however, added a number of safeguards in an attempt to get the recording as accurate as possible. The method which we employed was as follows.

After the subjects had been selected and had agreed to co-operate, each was interviewed. At the interview the object of the survey was explained and each person was given a log-book in which he was asked to record in spoonfuls, cupfuls, number of slices, etc., the quantities of every item of food eaten. It was stressed that records should be made as soon as possible after each meal. An appointment was made for the following day. At this, a dietitian went over the log-book and assessed the exact quantity of each article of food. In order to help in determining the weight of each item, a selection

\section{PYKE, AND G. M. WARNOCK}

of nearly two hundred portions of common foods? ready for consumption was displayed on a table $\vec{F}$ For example slices of bread of varying thicknesses and from loaves of different shapes, different types: of sausages, thick and thin portions of cookects. meats, fish, etc., various kinds of both cooked anc uncooked vegetables, samples of the fresh fruits available at the time, stewed fruits, and a wides variety of cakes, buns, scones and biscuits, portions of butter, jams, etc., were all included in this display The foods were displayed as for serving and the्w actual weight of each sample, when first prepared was recorded. Formalin was used to preserve somes of the meats, but many samples had to be replacedt frequently to avoid shrinkage and desiccation.Every attempt was made to include all items in thisD display and if a student had consumed something not on display, it was obtained for the following day A number of subjects brought from home duplicate samples of less familiar foods, if he or she founde the quantity difficult to describe to the dietitian In addition four different portions of each type of food served in the men's and women's Unions $\odot$ where many of the students had their mid-daye meals, were weighed. Buns, cakes, etc., as served at the snack counters, were weighed, and similarlys cakes and buns from the popular restaurant in the vicinity of the University.

The students recorded their food consumption fo 8 eight consecutive days. The first day's record was. considered as a trial and discarded. An attemps was made to fix interviews with the dietitians every day during the week except Sunday. This was not always possible, but each student had at least five. interviews and many had more. All the dietitians employed had had considerable experience of̂ survey work, and this was very valuable in enabling them to assist the students clearly to identify the foods they recorded in their log-books and to make quantitative comparisons with the weighed foodso

Finally, the great majority of the students had an interview with the whole investigating team three. or four months after the recording had finished At this interview the records had been added up and analysed and the results shown to each studentr It was possible to discuss any apparent anomaließ and to discard a few surveys (less than 2 per cent.) iv which the recording had been obviously incomplete or in which, owing to illness or other circumstances the diet for the week had clearly been different fronff the usual pattern. At this interview much informa-O tion was obtained about the student's persona $\widehat{P}_{\text {P }}$ attitude to food, his or her likes and dislikes, an\$ how each reacted to food restrictions and rationing $\mathrm{B}_{\mathbb{D}}$

It is extremely difficult to assess the accuracy of 
the questionnaire method. The only check that we have been able to carry out has been a small comparison with the weighing technique. Students who were living at home and seldom ate out were asked if they were willing to repeat the recording for a further seven days in exactly the same fashion, but on the second occasion actually weighing and recording each item of food before consumption.

Only eight volunteered to undertake a weighed survey and this, in itself, is an example of the difficulties and limitations of the weighing technique. Table II shows the average daily nutrient intake of these eight subjects according to the two methods of assay.

\section{TABLE II}

Average DaIly Intake of Calories and Nutrients FOUND IN EIGHT SubJeCTS BY TWO DifFERENT SURVEY Methods during two Consecutive Periods of Seven DAYS

\begin{tabular}{|c|c|c|c|}
\hline & & Weighing & Questionnaire \\
\hline 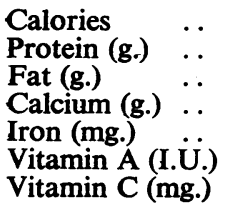 & $\begin{array}{l}. . \\
. . \\
. . \\
. . \\
\ldots\end{array}$ & $\begin{array}{r}2,660 \\
90 \\
94 \\
1 \cdot 0 \\
18 \\
4,500 \\
72\end{array}$ & $\begin{array}{r}2,710 \\
94 \\
105 \\
1 \cdot 0 \\
19 \\
4,300 \\
65\end{array}$ \\
\hline
\end{tabular}

The check, as far as it goes, confirms Bransby and others (1948) in the general conclusion that the weighing and questioning method can give approximately the same average values for energy and nutrients under certain conditions. While this may be so for average values, greater variations occur in individual diets.

Individual differences in the average daily calorie consumption were all under three hundred calories. Boulton (1945), quoted by. Widdowson (1947), found similar variations when she studied the average daily consumption over a period of four consecutive weeks using the weighing method all the time. It would, of course, have been ideal to have had both methods in operation during the same week but the method could not be checked by asking the subject to weigh his food and later during the same day describe it at an interview. It is, too, of interest to note that in spite of the fact that each subject had gained some experience in recording during the first week, we still found, on all books except one, one or two items insufficiently recorded. Where the weighing technique is being carried out by the subject without any personal contact with the investigator it seems highly probable that a number of adjustments will be necessary before the calculation of the diet in terms of calories, etc., can be carried out.

It is clear, on both theoretical and practical grounds, that it is impossible to check accurately any method for carrying out individual diet surveys. A diet survey is a complicated sociological process in which conditions cannot be controlled and repeated as in a chemistry laboratory. The final test of the value of any survey method is the practical value of the conclusions that can be drawn from.it.

\section{RESULTS}

Average Daily Consumption of Nutrients.Even a small diet survey means the collection of a vast amount of data. The selection of the best method of presentation of the data involves diffculties. The most usual method is to convert the quantities of foodstuffs consumed into calories and nutrients. Daily consumption of each of these is determined and recorded, sometimes with a range of extreme values and with a calculation of the standard deviation of the values. We have followed this practice, and Table III records average daily consumption of calories and nutrients. Such a table provides a convenient method for summarizing the results of a survey in chemical terms. The preparation, however, necessitating the use of a detailed table of food analyses involves a considerable additional source of error. Our results have been calculated from tables in use at the Ministry of Food, which, with certain modifications, are based on The Nutritive Value of Wartime Foods (Accessory Food Factors Committee, 1945) and The Chemical Composition of Foods (McCance and Widdowson, 1946).

For made-up dishes, it is inevitable that there must be considerable variations in the recipes used for their preparation, each differing from the samples analysed for the preparation of the tables. Where the ingredients of an individual dish were known, the analyses were based on this information. Bransby and others (1947) have shown that assessments of diets using standard food analysis tables may differ in important respects from an assessment of the same diets obtained by chemical analysis of aliquot samples of food consumed.

Age, height, and weights are recorded in Table IIIA, and the American National Research Council Recommendations for dietary allowances (as revised in 1948) in Table IIIB. It is difficult to know with which N.R.C. class Edinburgh students may be best compared, for the average ages of all our groups was 19 and so they were not strictly comparable with the 16-20 group. Average weights for our men 
TABLE III

Nutritive Value of Dietary Intake of Various Groups

\begin{tabular}{|c|c|c|c|c|c|c|c|}
\hline & & \multicolumn{3}{|c|}{ Men } & \multicolumn{3}{|c|}{ Women } \\
\hline & & At home & In lodgings & Hostels & At home & In lodgings & Hostels \\
\hline Calories & $\begin{array}{r}\mathbf{M} \\
\mathbf{R}\end{array}$ & $\begin{array}{l}3,040 \pm 580 \\
2,140-4,690\end{array}$ & $\begin{array}{l}2,900 \pm 470 \\
2,150-3,870\end{array}$ & $\begin{array}{l}2,960 \pm 290 \\
2,440-3,590\end{array}$ & $\begin{array}{l}2,180 \pm 370 \\
1,450-3,160\end{array}$ & $\begin{array}{l}2,280 \pm 400 \\
1,520-3,220\end{array}$ & $\begin{array}{l}2,330 \pm 310 \\
1,750-3,080\end{array}$ \\
\hline $\begin{array}{l}\text { Total protein I } \\
\text { (g.) }\end{array}$ & $\begin{array}{r}\mathbf{M} \\
\mathbf{R}\end{array}$ & $\begin{array}{c}101 \pm 19 \\
74-163\end{array}$ & $\begin{array}{c}102 \pm 15 \\
77-137\end{array}$ & $\begin{array}{l}97 \pm 11 \\
81-109\end{array}$ & $\begin{array}{l}76 \pm 13 \\
51-118\end{array}$ & $\begin{array}{l}78 \pm 13 \\
49-102\end{array}$ & $\begin{array}{l}79 \pm 12 \\
56-99\end{array}$ \\
\hline $\begin{array}{l}\text { Animal } \\
\text { protein (g.) }\end{array}$ & $\begin{array}{l}\mathrm{M} \\
\mathrm{R}\end{array}$ & $\begin{array}{l}45 \pm 11 \\
30-77\end{array}$ & $\begin{array}{l}47 \pm 9 \\
30-62\end{array}$ & $\begin{array}{l}39 \pm 7 \\
25-58\end{array}$ & $\begin{array}{l}39 \pm 10 \\
20-76\end{array}$ & $\begin{array}{l}38 \pm 8 \\
20-61\end{array}$ & $\begin{array}{l}38 \pm 8 \\
21-51\end{array}$ \\
\hline Fat (g.) & $\begin{array}{c}\mathbf{M} \\
\mathbf{R}\end{array}$ & $\begin{array}{c}106 \pm 23 \\
64-185\end{array}$ & $\begin{aligned} 101 & \pm 20 \\
67 & -153\end{aligned}$ & $\begin{array}{l}92 \pm 15 \\
70-122\end{array}$ & $\begin{array}{l}81 \pm 16 \\
52-111\end{array}$ & $\begin{array}{l}83 \pm 15 \\
51-116\end{array}$ & $\begin{array}{l}89 \pm 15 \\
71-142\end{array}$ \\
\hline Calcium (g.) & $\begin{array}{r}\mathbf{M} \\
\mathbf{R}\end{array}$ & $\begin{array}{l}1 \cdot 2 \pm 0 \cdot 3 \\
0 \cdot 7-1 \cdot 7 \\
\end{array}$ & $\begin{array}{l}1 \cdot 1 \pm 0 \cdot 2 \\
0 \cdot 6 \cdot 1 \cdot 7 \\
\end{array}$ & $\begin{array}{l}1 \cdot 2 \pm 0 \cdot 2 \\
0 \cdot 9 \cdot 1 \cdot 7 \\
\end{array}$ & $\begin{array}{l}0 \cdot 9 \pm 0 \cdot 2 \\
0 \cdot 4-1 \cdot 3\end{array}$ & $\begin{array}{l}0.9 \pm 0 \cdot 2 \\
0 \cdot 5-1 \cdot 3\end{array}$ & $\begin{array}{l}0 \cdot 8 \pm 0 \cdot 1 \\
0 \cdot 5-1 \cdot 0 \\
\end{array}$ \\
\hline Iron (mg.) & $\begin{array}{c}\mathbf{M} \\
\mathbf{R}\end{array}$ & $\begin{array}{l}20 \pm 4 \\
12-34\end{array}$ & $\begin{array}{l}21 \pm 3 \\
15-28\end{array}$ & $\begin{array}{l}22 \pm 3 \\
17: 26\end{array}$ & $\begin{array}{l}15 \pm 3 \\
10-26\end{array}$ & $\begin{array}{c}16 \pm 3 \\
9-24\end{array}$ & $\begin{array}{l}18 \pm 3 \\
12-23\end{array}$ \\
\hline $\begin{array}{c}\text { Vitamin } \\
\text { (I.U.) }\end{array}$ & $\underset{\mathbf{R}}{\mathbf{M}}$ & $\begin{array}{l}4,800 \pm 2,300 \\
1,600-11,300\end{array}$ & $\begin{array}{l}4,800 \pm 2,100 \\
1,000-9,800\end{array}$ & $\begin{array}{l}6,700 \pm 1,800 \\
4,900-12,300\end{array}$ & $\begin{array}{l}3,400 \pm 1,800 \\
1,000-10,300\end{array}$ & $\begin{array}{l}4,300 \pm 1,900 \\
1,100-11,500\end{array}$ & $\begin{array}{l}5,800 \pm 2,400 \\
2,500-10,900\end{array}$ \\
\hline$\underset{\text { (mg.) }}{\text { Vitamin }} B_{1}$ & $\begin{array}{c}\mathbf{M} \\
\mathbf{R}\end{array}$ & $\begin{array}{l}1 \cdot 7 \pm 0 \cdot 4 \\
1 \cdot 1-2 \cdot 7\end{array}$ & $\begin{array}{l}1 \cdot 7 \pm 0 \cdot 3 \\
1 \cdot 0-2 \cdot 2\end{array}$ & $\begin{array}{l}1 \cdot 7 \pm 0 \cdot 2 \\
1 \cdot 4-2 \cdot 2\end{array}$ & $\begin{array}{l}1 \cdot 2 \pm 0 \cdot 2 \\
0 \cdot 7-2 \cdot 0\end{array}$ & $\begin{array}{l}1 \cdot 2 \pm 0 \cdot 3 \\
0 \cdot 7-2 \cdot 2\end{array}$ & $\begin{array}{l}1 \cdot 2 \pm 0 \cdot 2 \\
0.9-1 \cdot 5\end{array}$ \\
\hline $\begin{array}{l}\text { Riboflavin } \\
\text { (mg.) }\end{array}$ & $\begin{array}{c}\mathbf{M} \\
\mathbf{R}\end{array}$ & $\begin{array}{l}1 \cdot 7 \pm 0 \cdot 4 \\
1 \cdot 1-2 \cdot 7\end{array}$ & $\begin{array}{l}1 \cdot 6 \pm 0 \cdot 3 \\
1 \cdot 1-2 \cdot 2\end{array}$ & $\begin{array}{l}1 \cdot 8 \pm 0 \cdot 3 \\
1 \cdot 4-2 \cdot 3\end{array}$ & $\begin{array}{l}1 \cdot 3 \pm 0 \cdot 3 \\
0 \cdot 8-2 \cdot 2\end{array}$ & $\begin{array}{l}1 \cdot 3 \pm 0 \cdot 2 \\
0 \cdot 7-2 \cdot 1\end{array}$ & $\begin{array}{l}1.4 \pm 0.3 \\
0.7-1.9\end{array}$ \\
\hline $\begin{array}{l}\text { Niacin } \\
\text { (mg.) }\end{array}$ & $\begin{array}{c}\mathbf{M} \\
\mathbf{R}\end{array}$ & $\begin{array}{l}14 \pm 3 \\
10-22\end{array}$ & $\begin{array}{c}14 \pm 3 \\
8-23\end{array}$ & $\begin{array}{l}17 \pm 5 \\
12-31\end{array}$ & $\begin{array}{c}10 \pm 2 \\
6-16\end{array}$ & $\begin{array}{c}11 \pm 3 \\
6-14\end{array}$ & $\begin{array}{l}11 \pm 2 \\
7-14\end{array}$ \\
\hline $\begin{array}{l}\text { Vitamin C } \\
\text { (mg.) }\end{array}$ & $\begin{array}{c}\mathbf{M} \\
\mathbf{R}\end{array}$ & $\begin{array}{l}75 \pm 45 \\
20 \div 160\end{array}$ & $\begin{array}{l}55 \pm 26 \\
20-120\end{array}$ & $\begin{array}{l}60 \pm 15 \\
40-100\end{array}$ & $\begin{array}{l}60 \pm 30 \\
15-125\end{array}$ & $\begin{array}{l}60 \pm 30 \\
20-120\end{array}$ & $\begin{array}{l}50 \pm 10 \\
40-85\end{array}$ \\
\hline
\end{tabular}

M-Mean. $\quad \pm$-Standard deviation. $\quad R-$ Range of extreme values.

TABLE IIIA

Age, Height, and Weight of Subjects

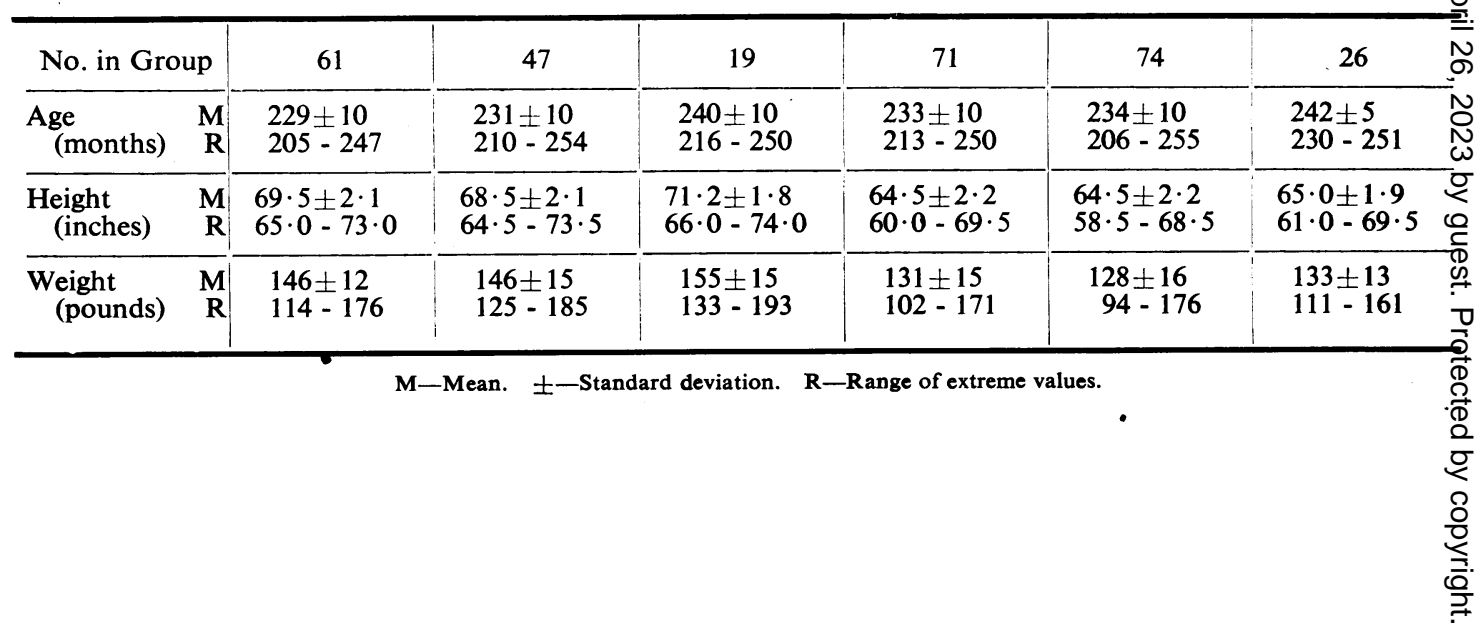


TABLE IIIB

Recommended Daily Dietary Allowances, food and Nutrition Board, National Research Council

\begin{tabular}{|c|c|c|c|c|c|c|c|c|c|}
\hline & Calories & $\begin{array}{l}\text { Protein } \\
\text { (g.) }\end{array}$ & $\underset{\text { (g.) }}{\text { Calcium }}$ & $\begin{array}{l}\text { Iron } \\
\text { (mg.) }\end{array}$ & $\begin{array}{c}\text { Vitamin } \\
\text { A } \\
\text { (I.U.) }\end{array}$ & $\begin{array}{l}\text { Thia- } \\
\text { mine } \\
\text { (mg.) }\end{array}$ & $\begin{array}{l}\text { Ribo- } \\
\text { flavin } \\
\text { (mg.) }\end{array}$ & $\begin{array}{c}\text { Niacin } \\
\text { (mg.) }\end{array}$ & $\begin{array}{l}\text { Ascorbic } \\
\text { acid } \\
\text { (mg.) }\end{array}$ \\
\hline $\begin{array}{l}\text { Man-156 lb. } \\
\text { Sedentary } \\
\text { Physically active } \ldots \\
\text { Boy } 16-20 \text { years }(141 \mathrm{lb} .)\end{array}$ & $\begin{array}{l}2,400 \\
3,000 \\
3,800\end{array}$ & $\begin{array}{r}70 \\
70 \\
100\end{array}$ & $\begin{array}{l}1 \cdot 0 \\
1.0 \\
1 \cdot 4\end{array}$ & $\begin{array}{l}12 \\
12 \\
15\end{array}$ & $\begin{array}{l}5,000 \\
5,000 \\
6,000\end{array}$ & $\begin{array}{l}1 \cdot 2 \\
1 \cdot 5 \\
1 \cdot 7\end{array}$ & $\begin{array}{l}1 \cdot 8 \\
1 \cdot 8 \\
2 \cdot 5\end{array}$ & $\begin{array}{r}-12 \\
15 \\
17\end{array}$ & $\begin{array}{r}75 \\
75 \\
100\end{array}$ \\
\hline $\begin{array}{l}\text { Woman-125 lb. } \\
\text { Sedentary } \\
\text { Moderately active } \\
\text { Girl 16-20 years }(119 \mathrm{lb} .)\end{array}$ & $\begin{array}{l}2,000 \\
2,400 \\
2,400\end{array}$ & $\begin{array}{l}60 \\
60 \\
75\end{array}$ & $\begin{array}{l}1.0 \\
1.0 \\
1.0\end{array}$ & $\begin{array}{l}12 \\
12 \\
15\end{array}$ & $\begin{array}{l}5,000 \\
5,000 \\
5,000\end{array}$ & $\begin{array}{l}1 \cdot 0 \\
1 \cdot 2 \\
1 \cdot 2\end{array}$ & $\begin{array}{l}1.5 \\
1.5 \\
1 \cdot 8\end{array}$ & $\begin{array}{l}10 \\
12 \\
12\end{array}$ & $\begin{array}{l}70 \\
70 \\
80\end{array}$ \\
\hline
\end{tabular}

were almost identical with the N.R.C. figure for an adult man, and for women our average weights were all higher than the N.R.C. figure for an adult woman.

Calories.-The average consumption of calories by all three groups of men was the same and almost identical with the N.R.C. recommendations for "Physically Active Man". For women, the average for all three groups fell between the N.R.C. figures for "Sedentary" and "Moderately Active Woman". These figures are consistent with the fact that our students could be described as "sedentary" for five days of the week, though many took vigorous athletic and other exercise at the week-ends. None of the students complained of an inability to obtain a sufficiency of energy-yielding foods. The figures probably reflect accurately the physiological requirements.

Protein.-The average total protein of all groups of both men and women were well above the N.R.C. recommendations for adults, and indeed in all cases, almost exactly on the higher levels recommended for adolescents. A very few individual women had low recorded intakes, but the study indicates that total protein consumption was satisfactory.

Animal Protein and Fat.-The N.R.C. gives no recommendations for these nutrients. In all groups of men and women, average consumption of animal protein was over 40 per cent. of the total protein intake, and the average consumption of fat provided over 30 per cent. of the total dietary calorie value. The fat consumption in the men's hostel was just below this figure, but this exception cannot alter the conclusion that, in respect of animal protein and fat, all groups had sufficient for physiological needs.

Calcium.-All three groups of men had average calcium intakes, midway between the N.R.C. recommendations for adults and for adolescents, but all three groups of women were below both standards. The higher figure for the men is a reflection of a higher bread intake with the additional calcium therein. The N.R.C. recommendations are high, and undoubtedly provide a wide safety margin. There can, however, be little doubt that some students, especially the women, with recorded intakes of 0.4 and $0.5 \mathrm{~g}$., were not taking what would be judged sufficient for satisfactory maintenance of bone.

Iron.-Consumption by men was adequate, and the averages for all groups of women satisfactory. However, individual women with recorded iron intakes of only 9 and $10 \mathrm{mg}$. were not obtaining a sufficiency. As will be described later, this is consistent with the presence of a mild anaemia in a small minority of the women.

Vitamin A.-During the survey week, the men's hostel had an extra supply of cheese, and the women's hostel an unusual supply of liver. These put up average vitamin $A$ intakes in the hostels. Vitamin A activities of the diets varied widely and depended to a great extent on individual consumption of carrot. As vitamin $\mathbf{A}$ can be stored in large amounts in the liver, low intakes during one week may be partly compensated for by large intakes of vitamin-A-rich foods in another week. Thus the very low recorded intakes in one week of some students may not give a true overall picture. Only 5 per cent. of the students took cod-liver oil or other vitamin A preparations regularly. Vitamin A from these sources has not been incorporated in group averages.

Vitamin $B_{1}$. - The average consumption for all groups appeared to be adequate, the quantity present in the diet varying proportionately with the calorie consumption.

Riboflavin.-The average values obtained were slightly lower than the N.R.C. recommendations, 


\section{BREAD and BUNS}

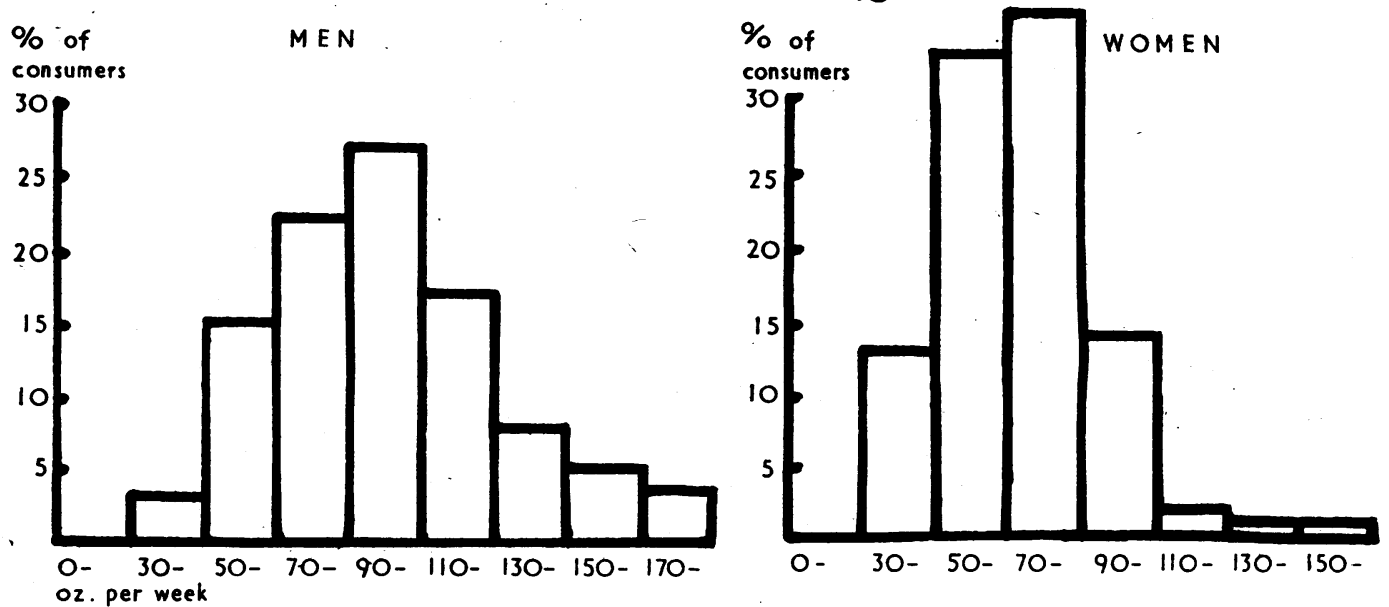

\section{POTATOES}
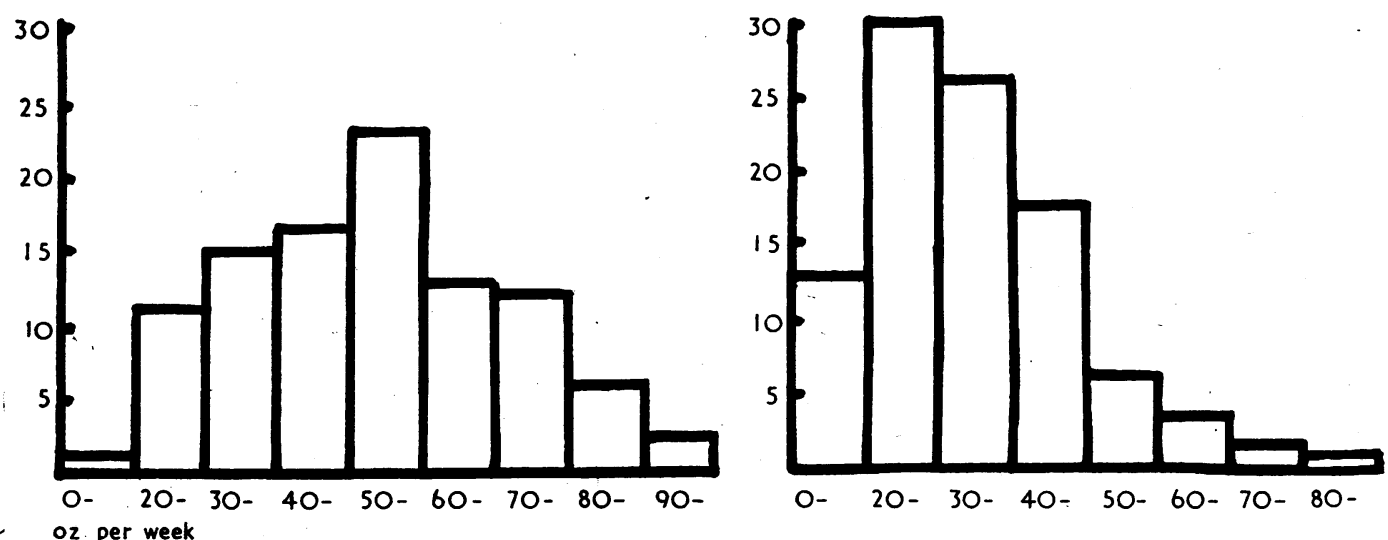
oz per week

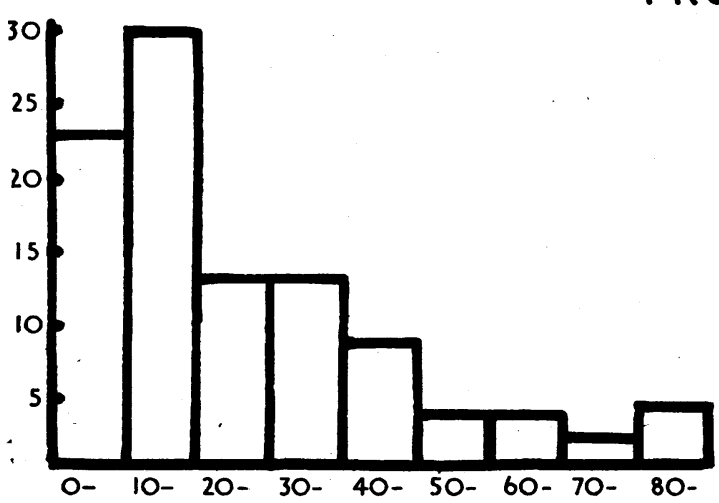

FRUIT

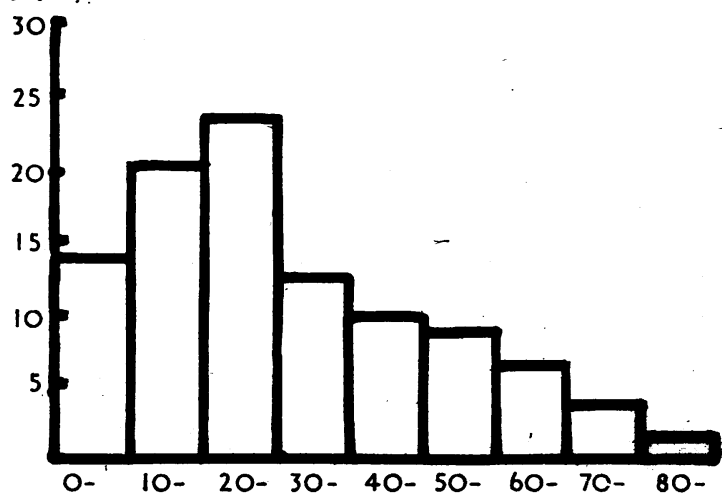

Fig. 1.-Consumption of bread and buns, potatoes, and fruit. 
CHEESE
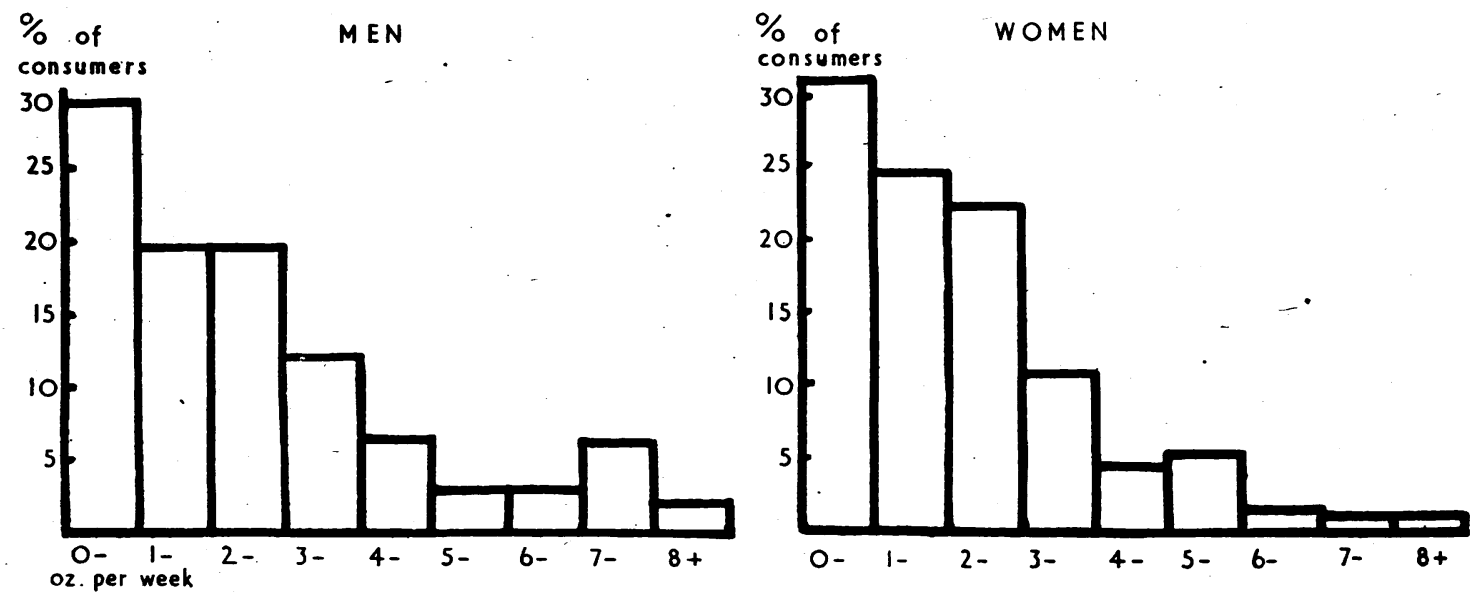

FISH
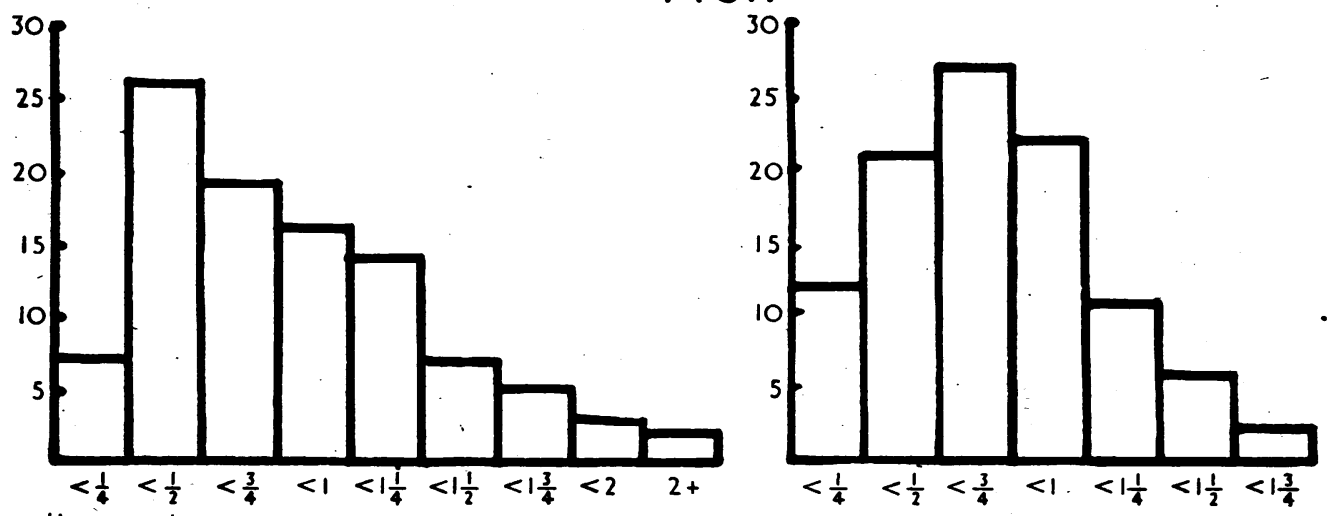

Ib. per week
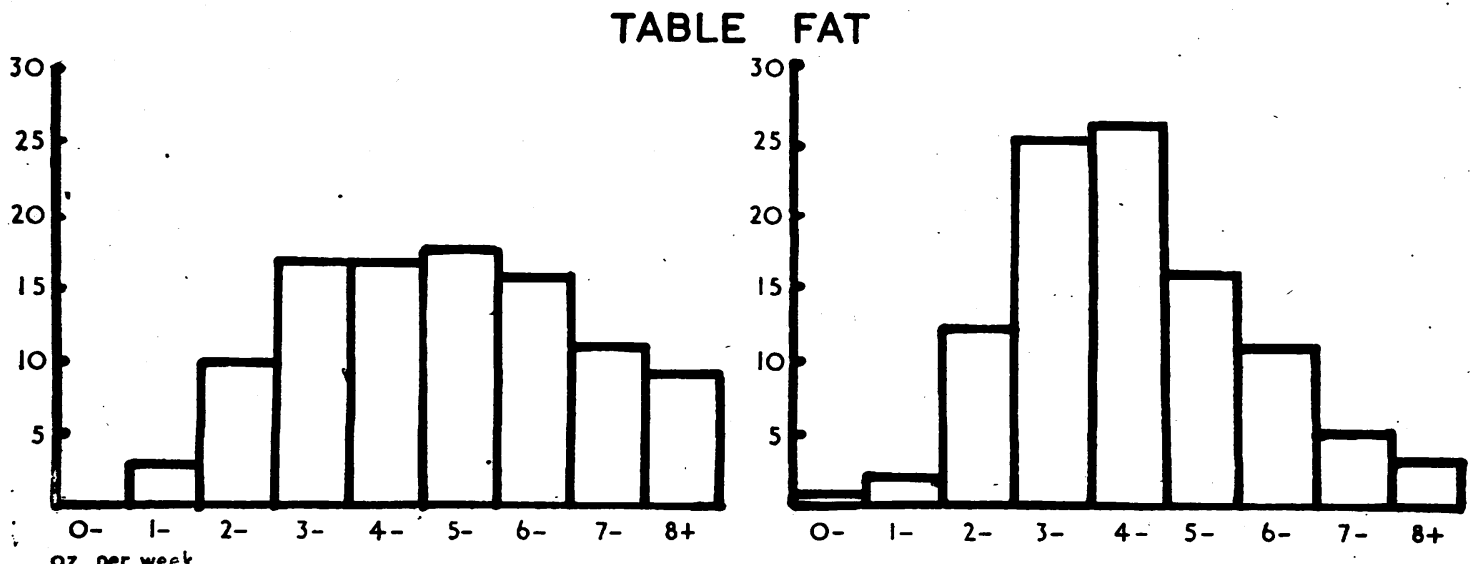

Fig. 2.-Consumption of cheese, fish, and table fats. 
the hostel groups being higher because of the inclusion of liver and cheese.

Nicotinic Acid.-As for riboflavin, the average values were approximately that suggested, but again the range was very wide. Only five subjects supplemented their diet by the addition of vitamin B complex from proprietary brands of foods or from synthetic sources.

Vitamin C.-Average vitamin C intake for the groups was satisfactory, but individual consumption varied widely. The low figures recorded in many individual surveys are a measure of the low consumption of fruit and vegetables, discussed in the next section. The table of analyses used gave values for cooked vegetables, and no consideration of losses in storage on hot plates was made. Some losses undoubtedly arise in this manner, and the average figures given are therefore probably a little high.

CONSUMPTION OF INDIVIDUALS' FoOdSTUFFs.-An alternative method of presentation is to record consumption of separate foodstuffs. In the tables which follow, this has been done. Instead of calculating a mean value for consumption and giving ranges, we have expressed the results as the number of persons under survey consuming a given quantity of food. In this way it is possible to show clearly the wide individual variations and also to relate these variations to the standard ration scales in force at the time, which were of necessity arbitrarily fixed.

The data which follow apply only to the 253 students living in lodgings or at home. The 44 students in hostels have not been included, since their diet was relatively standardized. The summary of the chemical analysis (Table III) shows that on the whole these hostel diets were satisfactory.

Cereals.-Table IV records the quantities of cereal in ounces per week consumed in the form of bread, cakes, buns, scones, etc. It does not include the relatively small amounts of cereal taken in the form of pudding, macaroni, porridge, or breakfast cereal. Wide differences in consumption occurred in both sexes, but none were found between those living at home and those in lodgings. No student said that he was unable to get enough bread; all said that they could eat as much of it as they desired. The official bread ration at the time for an adult was $63 \mathrm{oz}$. per week. There were clearly supplies to meet the demands of those who required more.

The eating of large quantities of cakes and buns is a characteristic of nearly all Edinburgh students. Most of the men and women took more than one-third of their total cereal as cakes or buns and
TABLE IV

ReCORDed CONSUMption OF Cereals

\begin{tabular}{c|r|r}
\hline \multirow{2}{*}{$\begin{array}{c}\text { Ounces of bread,cakes, and buns per } \\
\text { week }\end{array}$} & \multicolumn{2}{|c}{$\begin{array}{c}\text { Number of } \\
\text { students }\end{array}$} \\
\cline { 2 - 3 } & Men & Women \\
\hline $30-49$ & 3 & 19 \\
$50-69$ & 16 & 48 \\
$70-89$ & 24 & 52 \\
$90-109$ & 29 & 21 \\
$110-129$ & 9 & 3 \\
$130-149$ & 5 & 1 \\
$150-169$ & 4 & 1 \\
$170+$ & & 0 \\
\hline
\end{tabular}

often the proportion was over half. Women were found to eat slightly more buns than men.

The assessment of the amount of cereals consumed as puddings is difficult, as recipes vary greatly. The puddings most commonly taken were steamed puddings, tarts of various kinds, custard and semolina, though many more were met with occasionally. In about two-thirds of the diets of both men and women the weekly intake lay between 10 and $30 \mathrm{oz}$. The number of times per week that puddings were consumed is shown in Table $\mathrm{V}$. Again, no difference was found between those at home and those in lodgings.

TABLE V

Consumption of Puddings

\begin{tabular}{c|c|c}
\hline \multirow{2}{*}{ Number of times per week } & \multicolumn{2}{|c}{$\begin{array}{c}\text { Number of } \\
\text { students }\end{array}$} \\
\cline { 2 - 3 } & Men & Women \\
\hline 0 & 0 & 5 \\
1 & 10 & 3 \\
2 & 16 & 7 \\
3 & 28 & 51 \\
4 & 26 & 29 \\
5 & 17 & 28 \\
6 and over & & \\
\hline
\end{tabular}

Porridge no longer plays a predominant role in the diet of the Scottish student. Although it is frequently taken at breakfast, only one man ate it regularly at other times of the day. Table VI shows the frequency with which porridge was taken at breakfast.

There is a marked sex difference here. Whereas the majority of men had porridge for breakfast most days of the week, most women never touched it. 
TABLE VI

Consumption of Porridge

\begin{tabular}{|c|c|c|c|}
\hline \multirow{2}{*}{\multicolumn{2}{|c|}{ Number of times per week }} & \multicolumn{2}{|c|}{$\begin{array}{l}\text { Number of } \\
\text { students }\end{array}$} \\
\hline & & Men & Women \\
\hline $\begin{array}{l}\text { Never } \\
\text { Occasionally ( } 1-3 \text { times) } \\
\text { Frequently (4-7 times) }\end{array}$ & $\begin{array}{l}\cdots \\
\cdots \\
\cdots\end{array}$ & $\begin{array}{l}27 \\
18 \\
63\end{array}$ & $\begin{array}{l}84 \\
28 \\
33\end{array}$ \\
\hline
\end{tabular}

The shortage of milk is possibly one factor which discourages the eating of porridge.

Proprietary breakfast cereals are not important rivals to porridge in the traditional breakfast. Sixty per cent. of men and 60 per cent. of women did not consume any during the survey. Among those who did, the calories obtained from this source were few, as none ate more than $10 \mathrm{oz}$. in the week. Again shortage of milk and perhaps the high " points" value of these proprietary foods may have limited their consumption.

A small amount of oatmeal was consumed as oatcake. Twenty-five per cent. of both men and women took up to $10 \mathrm{oz}$. during the week, but for none of the students was this an important food.

Potatoes.-The recorded consumption is shown in Table VII.

TABLE VII

Recorded Consumption of Potatoes

\begin{tabular}{c|c|c}
\hline & \multicolumn{2}{|c}{$\begin{array}{c}\text { Number of } \\
\text { students }\end{array}$} \\
\cline { 2 - 3 } Oz. consumed per week & Men & Women \\
\hline $0-9$ & 0 & 6 \\
& $10-19$ & 13 \\
$20-29$ & 12 & 44 \\
$30-39$ & 18 & 39 \\
$40-49$ & 25 & 99 \\
$50-59$ & 14 & 5 \\
$60-69$ & 13 & 2 \\
$70-79$ & 9 & 1 \\
80 and over & & \\
\hline
\end{tabular}

No difference existed between those at home and those in lodgings, but it is clear that the men consumed much more than the women. At the time of the survey potatoes were rationed, the weekly allowance being $3 \mathrm{lb}$. This weight, of course, includes the peel, whereas the recorded consumption in Table VII does not. Fifty-six per cent. of men and 12 per cent. of women students recorded an intake of over $50 \mathrm{oz}$. in the week. Of these big potato-eaters, a few complained of the small size of helpings in restaurants and clubs, but none of any shortage at home or in lodgings. The extra potatoes were obtained in a variety of ways; some had supplies sent in from the country, others had access to private gardens or allotments; some depended on stores laid in before rationing started, and not a few stated that their greengrocers were meeting their needs in full. A large proportion of women, probably about 50 per cent., did not eat their full ration. No doubt much redistribution of rations occurred within families.

Vegetables. - The recorded consumption of vegetables (other than potatoes) is shown in Tables VIII and IX. Table VIII gives cooked weight of green vegetables - cabbages, brussels sprouts, cauliflowers, spinach, lettuces, etc. Table IX refers to other vegetables such as carrots, turnips, swedes, beetroots, parsnips, onions, leeks, peas, beans, etc.

TABLE VIII

Recorded Consumption of Green Vegetables

\begin{tabular}{c|c|c}
\hline \multirow{2}{*}{$\begin{array}{c}\cdot \\
\text { Oz. consumed per week }\end{array}$} & \multicolumn{2}{|c}{$\begin{array}{c}\text { Number of } \\
\text { students }\end{array}$} \\
\cline { 2 - 3 } & Men & Women \\
\hline $0-5$ & 73 & 91 \\
$6-10$ & 25 & 34 \\
Over 10 & 10 & 20 \\
\hline
\end{tabular}

TABLE IX

ReCORDED CONSUMPTION OF Other Vegetables

\begin{tabular}{c|c|c}
\hline & \multicolumn{2}{|c}{$\begin{array}{c}\text { Number of } \\
\text { students }\end{array}$} \\
\hline Oz. consumed per week & Men & Women \\
\hline $0-10$ & 52 & 79 \\
$11-20$ & 47 & 47 \\
$21-30$ & 7 & 18 \\
Over 30 & 2 & 1 \\
\hline
\end{tabular}

In neither case was any difference found between those living in lodgings and those at home.

These figures do not include the vegetables employed in making soups. Scotch broth is a traditional dish, consisting of a vegetable soup usually, but not always today, thickened with barley or other cereals. The weekly recorded consumption is given in Table $X$.

In those students taking less than a pint a week (about half the total number) this source of vegetables is negligible. In some of the others it may represent a very considerable intake. 
TABLE X

RECORDED CONSUMPTION OF SCOTCH BRoth

\begin{tabular}{c|c|c}
\hline & \multicolumn{2}{|c}{$\begin{array}{c}\text { Number of } \\
\text { students }\end{array}$} \\
\cline { 2 - 3 } Pints consumed per week & Men & Women \\
\hline Up to 1 & 45 & 78 \\
1 to 2 & 41 & 50 \\
2 to 3 & 13 & 15 \\
3 and over & 9 & 2 \\
\hline
\end{tabular}

Fruit.-During the period of the survey there was an abundance of oranges and grapefruits in the shops of Edinburgh. Tomatoes could also be obtained without difficulty. Table XI shows that, whilst some students ate large amounts of fruit, others took no advantage of the plentiful supplies available. Considerable differences existed both between the sexes and between those at home and in lodgings. Women ate more fruit than men, and those at home more than those in lodgings.

TABLE XI

Recorded Consumption of Fresh Fruit

\begin{tabular}{|c|c|c|c|c|}
\hline \multirow{2}{*}{$\begin{array}{l}\text { Oz. con- } \\
\text { sumed per } \\
\text { week }\end{array}$} & \multicolumn{4}{|c|}{ Numbers of } \\
\hline & $\begin{array}{l}\text { Men at } \\
\text { home }\end{array}$ & $\begin{array}{c}\text { Men in } \\
\text { lodgings }\end{array}$ & $\begin{array}{l}\text { Women at } \\
\text { home }\end{array}$ & $\begin{array}{l}\text { Women in } \\
\text { lodgings }\end{array}$ \\
\hline $\begin{array}{l}0-10 \\
11-20 \\
21-30 \\
31-40 \\
41-50 \\
\text { Over } 50\end{array}$ & $\begin{array}{r}9 \\
14 \\
9 \\
11 \\
8 \\
10\end{array}$ & $\begin{array}{r}16 \\
18 \\
5 \\
3 \\
1 \\
4\end{array}$ & $\begin{array}{r}8 \\
12 \\
19 \\
8 \\
6 \\
18\end{array}$ & $\begin{array}{r}12 \\
17 \\
15 \\
10 \\
8 \\
12\end{array}$ \\
\hline
\end{tabular}

Meat and Flesh Foods.-During the period of the survey the domestic ration of fresh butcher's meat for an adult was a shilling's worth. The amount purchased varied according to the quality of meat chosen. Table XII gives recorded consumption of fresh meat, including any obtained in restaurants and canteens. A few of the very low intakes are due to the student's not consuming his ration within the period of the survey.

Poultry, game, liver, and kidney were available as an additional source of fresh meat. These foods were unrationed, but not readily available and expensive. About half the men and one-third of the women had small quantities (up to $8 \mathrm{oz}$.) of meat in this form during the week. Only eight men and three women had larger amounts.

An additional source of meat are the " made-up "

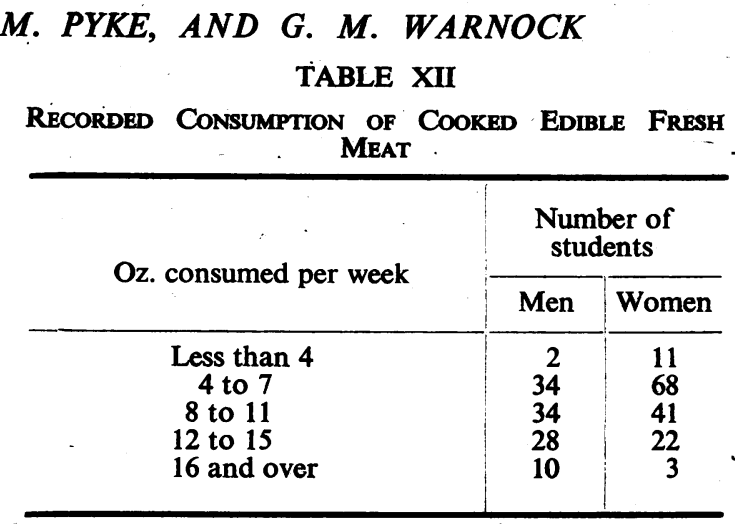

meat dishes such as sausages, meat pies, rissoles, mince, haggis, etc. The meat in these is always diluted with a considerable proportion of flour or other component. Nevertheless, these foods do $\vec{c}$ provide a considerable additional source of animal protein. Table XIII gives recorded consumption of " made-up " meats.

TABLE XIII

Recorded Consumption of Made-up Meats

\begin{tabular}{c|c|c}
\hline & \multicolumn{2}{|c}{$\begin{array}{c}\text { Number of } \\
\text { students }\end{array}$} \\
\cline { 2 - 3 } Oz. consumed per week & Men & Women \\
\hline Less than $\frac{1}{2}$ & 11 & 44 \\
$\frac{1}{2}$ to 1 & 31 & 69 \\
1 to $1 \frac{1}{2}$ & 39 & 25 \\
$1 \frac{1}{2}$ to 2 & 15 & 5 \\
Over 2 & 12 & 2 \\
\hline
\end{tabular}

The bacon ration throughout the survey was $2 \mathrm{oz}$. a head weekly. The great majority of students were probably eating this amount and no more. $₹$ Actual figures obtained in the survey show variations $\frac{\text { o }}{\square}$ which are probably due to the fact that people $>$ sometimes consume two weeks' ration of bacon in one week and none in the next. Very few (about N 5 per cent.) do not like bacon, and a correspondingly small number manage to get hold of these rations.

Throughout the survey fish was unrationed and $N_{\omega}$ readily available. Almost all students took advantage of this. Table XIV gives consumption of fish. The commonest kinds of fish eaten were herring and haddock, kippers, especially at breakfast, and cod, $\stackrel{?}{+}$ often served in restaurants. Almost all the quan- 0 tities recorded represent fresh fish, fish cakes and other made-up dishes occurring comparatively rarely. Fish consumption appeared to be the same $\stackrel{\mathbb{Q}}{\varrho}$ in lodgings as at home. 
TABLE XIV

Recorded Consumption of Fish

\begin{tabular}{c|c|c}
\hline \multirow{2}{*}{ Lb. consumed per week } & \multicolumn{2}{|c}{$\begin{array}{c}\text { Number of } \\
\text { students }\end{array}$} \\
\cline { 2 - 3 } & Men & Women \\
\hline Less than 1 & 8 & 18 \\
$\frac{1}{4}$ to $\frac{1}{2}$ & 28 & 30 \\
$\frac{1}{2}$ to $\frac{3}{4}$ & 17 & 39 \\
$\frac{3}{4}$ to 1 & 31 \\
1 to $1 \frac{1}{2}$ & 9 & 24 \\
$1 \frac{1}{2}$ to 2 & 2 & 0 \\
Over 2 & & 3 \\
\hline
\end{tabular}

Dairy Produce-Milk, Cheese, and Eggs.-At midwinter, milk production is at its lowest and the normal adult ration of two pints per week is a small allowance for a tea-and-coffee-drinking population such as the students. The great bulk of the milk was consumed in these beverages and only small amounts were left over for porridge, breakfast cereals, and puddings, and normally none for drinking as milk. The assessments of amounts of milk taken in tea and coffee is difficult. In 196 cases, the records indicated, and the students confirmed at interview, that only the ration of milk was being taken, with the addition of small quantities in tea and coffee at outside restaurants. Ten students indicated that they were not getting two pints per week. Of these, five women and one man stated that they disliked milk and seldom had it, even in tea or coffee. The remaining four were in lodgings and thought that they were not supplied with their due of milk. Forty-seven students (18 per cent.) recorded over two pints per week in addition to milk in tea and coffee. Of these, eleven lived in the country with access to farms, twenty-eight ascribed their good fortune to having a " good " milkman, and eight confessed to living in homes where there was priority milk or had friends or relations who disliked milk. None of them was eligible for more than the standard ration. The findings are summarized in Table XV.

Of the 18 per cent. reckoned to have got more than two pints exclusive of milk in tea and coffee, the assessed intake is given in Table XVI.

TABLE XVI

ReCORded MiLK CONSUMPTION OF StUdents With ACCess to an eXTra SuPply OF MilK

\begin{tabular}{c|c}
\hline $\begin{array}{c}\text { Pints of milk consumed } \\
\text { per week }\end{array}$ & Number of students \\
\hline $2-2 \cdot 9$ & 15 \\
$3-3 \cdot 9$ & 13 \\
$4-4 \cdot 9$ & 9 \\
$5-5 \cdot 9$ & 4 \\
$6-6 \cdot 9$ & 3 \\
$7-7 \cdot 9$ & 1 \\
$8-8 \cdot 9$ & 1 \\
over 9 & 1 \\
\hline
\end{tabular}

Cheese was rationed at $2 \mathrm{oz}$. a head weekly. In contrast to bacon and milk, of which foods most of the students consumed approximately the allotted ration, there was wide variation in the taste for cheese. Almost one-third, with equal proportion of men and women, stated that they did not like cheese. Some never ate it at all and others only ate it in cooked dishes such as savouries, macaroni cheese, etc. There is considerable competition amongst cheese-eaters for the unconsumed ration of the cheese-haters. Some complicated bartering systems existed. A few students were eating two, three, or even four times the official

TABLE XV

Milk Consumption

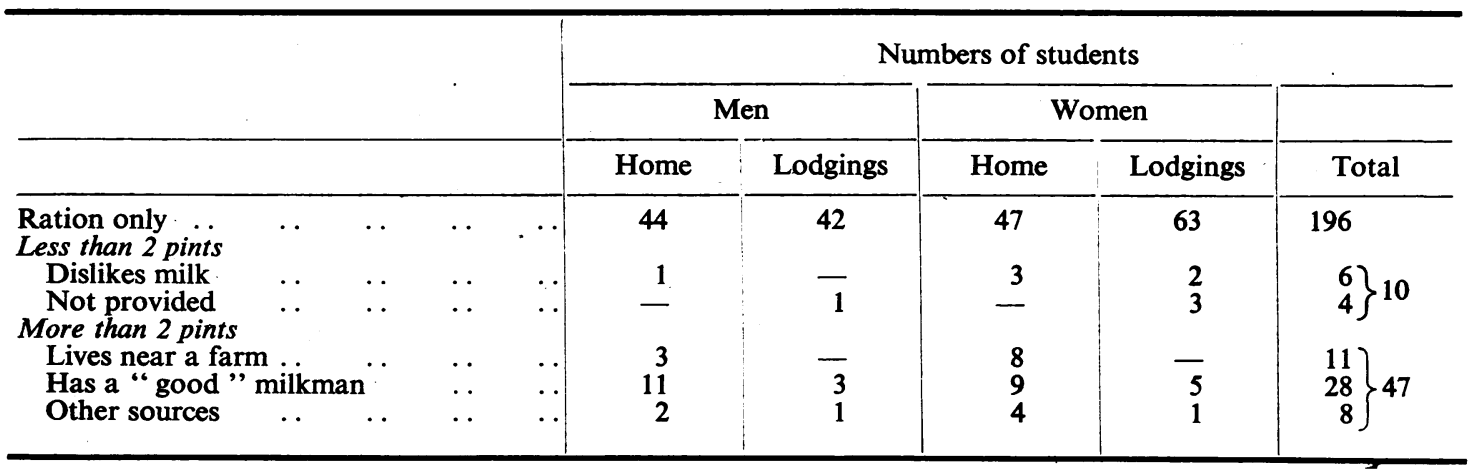


ration, and would have liked more. Some of the big cheese-eaters got extra supplies from overseas parcels. The survey showed that the vagaries of human taste thwarted the good intentions of those who would equitably distribute this source of first-class animal protein.

The allocation of eggs in Edinburgh varied slightly during the period of survey, but an average of two per week was available from grocers. Table XVII shows the number of shell eggs recorded. Again there is no significant difference between those living at home and in lodgings. Only twelve students did not have at least one egg in the week, and, of these, two never ate eggs in any circumstances.

\section{TABLE XVII}

Recorded Consumption of EgGs

\begin{tabular}{c|c|c}
\hline & \multicolumn{2}{|c}{$\begin{array}{c}\text { Number of } \\
\text { students }\end{array}$} \\
\cline { 2 - 3 } Number per week & Men & Women \\
\hline 0 & 2 & 10 \\
1 & 29 & 34 \\
2 & 20 & 33 \\
3 & 21 & 25 \\
4 & 11 & 5 \\
5 & 4 & 2 \\
6 & 3 & 3 \\
7 and over & & \\
\hline
\end{tabular}

Some reported that the week. of the survey was exceptional in that an allocation of three or four eggs was made to compensate for previous deficits. Nevertheless, at least half the students had sources of supply beyond the allocation. Of these sources, back-garden hens and friends in the country were the commonest. In addition to shell eggs, dried egg powder was consumed by most students. This is often incorporated into puddings and cakes, and the amount eaten by individual students cannot be assessed accurately.

Fats.-During the survey the ration of fats was $8 \mathrm{oz}$. per week, of which $3 \mathrm{oz}$. were butter, $4 \mathrm{oz}$. margarine, and $1 \mathrm{oz}$. cooking fat. Table XVIII gives recorded consumption of fat spread on bread (table fat) but excludes fat used in cooking.

Fat rationing was strictly enforced at the time and few students had access to an extra-ration supply. Only two got extra fat from overseas parcels, and two more from farm butter. Nevertheless, as Table XVIII shows, at least a quarter of the students recorded a consumption greater than $6 \mathrm{oz}$. of table fat a week, which, allowing only $1 \mathrm{oz}$. of margarine for cooking, means that they almost certainly ate
TABLE XVIII

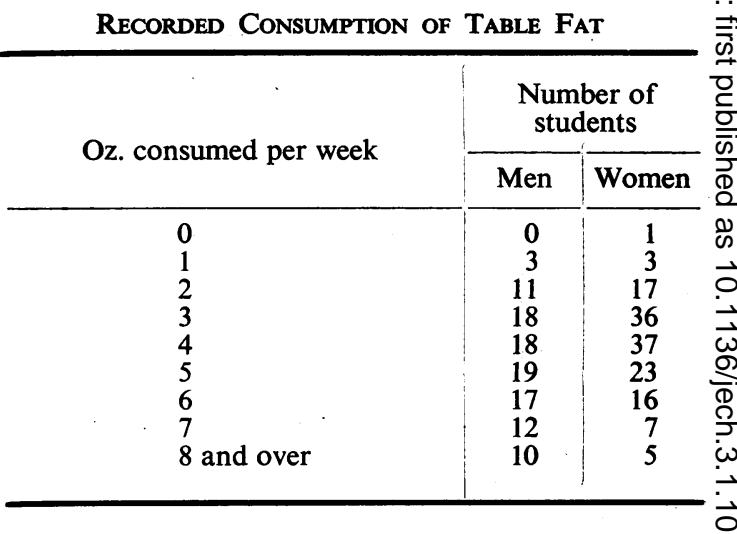

more than their ration. They were probably able 을 to do this because of unequal distribution within the household. For example, many of those in $\bar{c}$ lodgings shared rooms with a fellow lodger, who did not eat his or her share. Many who are small bréad-eaters do not require the full fat ration. Of the big fat-eaters living at home, most admitted to consuming part of their parents' ration, and one young man with a large appetite had, in addition, established a regular lien on a portion of his grandparents' fat ration.

Sugar and Jams. - During the period of the survey the sugar ration was $8 \mathrm{oz}$. and the jam ration $4 \mathrm{oz}$. a head weekly. The sugar was consumed mostly in tea, on porridge, and on puddings. Very few students had extra sources of supply, and the great majority consumed their ration, and their ration only, in this way. As regards jam consumption, there was wide variation. A few, especially amongst the small bread-eaters, did not eat their full ration, but many others consumed amounts 3 considerably in excess of their weekly ration. This was to be expected since jam can be stored and in 3 some families, apart from unequal consumption by 0 individual members, substantial supplies of homemade jam are laid down during the fruit season.

Beverages. - The principal drink of students of both sexes was found to be tea. Diaries recorded $\sigma$ an average consumption of tea seventeen times in N the course of a week. Variations from this average N were small, and it is quite exceptional for a student $\sigma$ not to have tea at least twice a day. The majority have milk in their tea, and a large proportion of the $\frac{C}{D}$ milk ration is taken in this way.

Coffee is the second most important beverage, $T$ being taken on an average five times a week. 0 However, many students drink it twice a day or $\mathbb{\mathbb { D }}$ more; others seldom or never. Coffee is drunk $\frac{\mathbb{D}}{\mathbb{D}}$ more in the Unions and restaurants than at home 
or in lodgings. As these are frequented mostly by students living in lodgings, the latter consume more coffee than those living at home.

Cocoa was taken on an average twice a week but with wide individual variations. Not more than one-third of the students ever drank National Milk Cocoa.

Beer consumption is shown in Table XIX.

TABLE XIX

RECORDED BeER CONSUMPTION

\begin{tabular}{|c|c|c|c|c|c|}
\hline \multirow{2}{*}{\multicolumn{3}{|c|}{ Pints of beer drunk per week }} & & \multicolumn{2}{|c|}{$\begin{array}{l}\text { Number of } \\
\text { students }\end{array}$} \\
\hline & & & & Men & Women \\
\hline $\begin{array}{ll}\text { Never } & \ldots \\
\text { Occasionally } & . . \\
1 \text { pint } & \ldots \\
2 \text { pints } & \ldots \\
3 \text { pints } & \ldots \\
4 \text { pints } \\
5 \text { pints and over }\end{array}$ & $\begin{array}{l}\ldots \\
\cdots \\
\cdots \\
\cdots \\
\cdots \\
\cdots\end{array}$ & $\begin{array}{l}. \\
\cdots \\
\cdots \\
\cdots \\
\cdots \\
\cdots \\
\cdots\end{array}$ & $\begin{array}{l}. . \\
\cdots \\
. \\
. \\
. \\
.\end{array}$ & $\begin{array}{r}54 \\
30 \\
10 \\
2 \\
4 \\
3 \\
5\end{array}$ & $\begin{array}{r}78 \\
60 \\
5 \\
1 \\
1\end{array}$ \\
\hline
\end{tabular}

In addition small quantities of wine and spirits were taken by six men and twelve women. Of those taking part in the survey 83 per cent. of men and 91 per cent. of women stated that they either never drank or only did so on special occasions. These figures confirm a general impression that present-day Edinburgh students are both abstemious and sober. Apart from any other considerations, the high taxation on alcoholic drinks must restrict their consumption.

Tobacco.-At the interviews the students were asked their usual consumption of tobacco, and this is shown in Table XX.

TABLE XX

Recorded Number of Cigarettes SMOKed

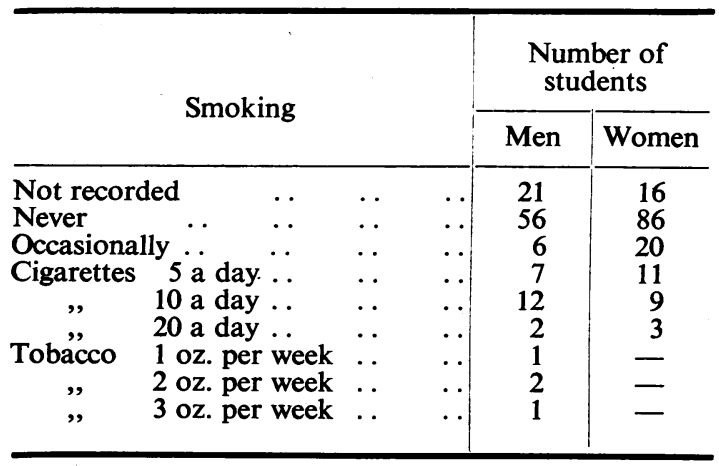

It will be seen that 62 (71 per cent.) of the men and 106 (82 per cent.) of the women never smoked or only did so occasionally. As in the case of alcohol, it is probable that high taxation acted as a deterrent.

\section{The Pattern of Student Meals}

A statement such as we have given, of total food intake of a group of people over a short period, provides an incomplete picture of the quality of their diets. It is important to know also how food consumption is spread throughout the day, how many meals are taken, and how these are related to social customs and working habits. A reader of the classical literature of any country will be aware how variable and changeable such human food habits are.

The present surveys show that with rare exceptions Edinburgh students eat their food in three main meals. These are a breakfast in the early morning, usually between 7.30 and 8.30 a.m., a mid-day meal taken between noon and 1.30 p.m., and an evening meal between 5.30 and 8 p.m. In addition most students have light refreshment or a snack at least once during the day. Snacks are usually taken at the middle of the forenoon or the middle of the afternoon or late at night before retiring to bed. Thus there are students who eat six times a day, others who have only three meals, but the majority eat between four and five times a day. We know little about how these varying habits affect human well-being and effective working. Human physiology has no precise information about the size of meals or the intervals between them that are optima for health. That adequate opportunity for the eating of proper meals is essential for efficient working is now widely realized; many practical industrialists and combatant officers in the Services have given considerable thought to the pattern of the meals of the men and women for whose health they are responsible. An account of the distribution of students' food intake throughout the day is relevant to considerations of student health.

Breakfast.-The day is usually begun with a meal in which bread with butter or margarine and marmalade or jam, together with tea (or occasionally coffee) are consumed. In addition this meal may include either or both oatmeal porridge and a cooked dish. The latter is usually an egg, bacon, sausage, kipper, herring, or other fish, and is important as providing a supply of animal protein. Meals with these additions conform to traditional Scottish and English customs. Without them a breakfast can be described as continental. The table shows the percentage of students consuming 
each type of breakfast. Not a few students had grapefruit on occasions, but otherwise fruit was rarely and vegetables hardly ever taken. Those who took porridge usually had the major portion of their milk ration at breakfast. The figures shown in the table are averages for the seven days in the week. Daily average figures show uniformity for the six weekdays, but on Sunday there is a great reduction in the number of those taking porridge and an increase in those eating cooked dishes-up to 80 per cent. of all students. Indeed, Sunday morning is frequently an occasion on which the limited week's ration of eggs and bacon is consumed in entirety.

TABLE XXI

Percentage of Students Consuming a given Type of BREAKFAST

\begin{tabular}{|c|c|c|c|c|}
\hline & \multicolumn{2}{|c|}{ Men } & \multicolumn{2}{|c|}{ Women } \\
\hline & Home & Lodgings & Home & Lodgings \\
\hline $\begin{array}{l}\text { Porridge and } \\
\text { cooked dish } \\
\text { Porridge only } \\
\text { Cooked dish } \\
\text { Continental type }\end{array}$ & $\begin{array}{l}20 \\
29 \\
29 \\
22\end{array}$ & $\begin{array}{r}41 \\
11 \\
42 \\
6\end{array}$ & $\begin{array}{r}8 \\
13 \\
43 \\
36\end{array}$ & $\begin{array}{r}19 \\
9 \\
57 \\
15\end{array}$ \\
\hline
\end{tabular}

These figures illustrate several features of students' breakfasts. Firstly, as already noted, they show that porridge is consumed regularly by only half the men and a small minority of the women. Secondly, more cooking for breakfast is done in lodgings than in the homes. Thirdly, men students tend to consume a more substantial breakfast than women. A striking feature is the large numbers who leave home for their day's work fortified only by tea or coffee and bread or toast. No less than 36 per cent. of women and 22 per cent. of men living at home come within this category. These have abandoned the traditional breakfasts of the country. The strict rationing of eggs and bacon and the limited supply of sausages and offal such as kidney, liver, etc., makes the task of procuring suitable foods for breakfast difficult and demands skill and patience in shopping. It is notable that in this respect landladies appear to be appreciably more effective than mothers. Some of those eating only small breakfasts do so from choice. They lie late in bed and have neither the time nor the inclination for a proper meal before setting out for work. These are for the most part girls. Those students who have to travel far from homes in the country must perforce rise earlier than others, yet they. usually got good breakfasts.

\section{M.- PYKE, AND G. M. WARNOCK}

The fact that large numbers of students come to classes without proper meals in the morning is an important factor contributing to the habit of taking mid-morning snacks.

The Mid-day Meal.-The great majority of students eat their mid-day meal either at a University Union or a city restaurant. This is shown in Table XXII.

TABLE XXII

Place of Taking Mid-day Meal

\begin{tabular}{c|c}
\hline Students' living location & $\begin{array}{c}\text { Percentage lunching } \\
\text { out }\end{array}$ \\
\hline $\begin{array}{l}\text { In lodgings mi. .. } \\
\text { At home 20 minutes or more }\end{array}$ & 86 \\
$\begin{array}{l}\text { from the University ... } \\
\text { At home within 20 minutes of } \\
\text { the University .. }\end{array}$ & 80 \\
\hline
\end{tabular}

A small proportion of landladies (about 10 per cent.) provide mid-day meals for students. The majority only contract to supply lunches on Saturday and Sunday. Students living in such lodgings are therefore forced to go elsewhere for their mid-day meals.

The chief factor determining where a homestudent eats at mid-day is the time available. This depends both upon travelling time and teaching schedules. Of the 130 students living at home, travelling times were as follows:

\begin{tabular}{|c|c|c|c|}
\hline Twenty minutes 0 & & & .. $35 \%$ \\
\hline 21 to 30 minutes & - & & $29 \%$ \\
\hline 31 to 60 minutes & . & & $23 \%$ \\
\hline Over one hour . & .. & $\cdots$ & $13 \%$ \\
\hline
\end{tabular}

Those living more than twenty minutes away are all forced to find their lunch out, except for a few Arts students who only occasionally have a class in the afternoon and who can return home to lunch and study at leisure. In general the luncheon interval is ample in the Arts faculty, limited in the Medical faculty, and often very limited in the Science faculty and first year in Medicine. This is reflected in students' lunching habits. Thus 33 out of 57 (58 per cent.) Arts students living at home have mid-day meals at home, but only 3 out of 52 (6 per cent.) Medicals and 1 out of 23 Science students. The majority of these students who have the time prefer to go home for their mid-day meal rather than lunch out. How big this majority is we cannot be sure, but it certainly is not less than 58 per cent., the figure for all Arts students. On 
being questioned, these have repeatedly assured us that there was always plenty of food at home. We looked for, but could find no correlation between the lunching habits and the number of ration books available to the housekeeper.

It was clear that the University Unions were more popular than city restaurants. On any given day the percentage of all students eating out, who used the Unions, was as follows:

$\begin{array}{llll}\text { Men living at home } & \ldots & \ldots & \mathbf{8 7} \% \\ \text { Men living in lodgings } & \ldots & \ldots & 71 \% \\ \text { Women living at home } & \ldots & \ldots & \mathbf{7 0} \% \\ \text { Women living in lodgings } & \ldots & \ldots & \mathbf{6 7 \%}\end{array}$

Those who did not use the Unions all complained of the poor service and overcrowding there. They stated that they were able to get meals quicker elsewhere. There was almost unanimity amongst the men that the Union provided as good a meal at as cheap a price as any city restaurant. Most of the women supported this opinion, but a considerable minority complained of lack of variety in the menus and of lack of imagination in the cooking and catering. The main complaint was of the service, and this was undoubtedly insufficient in both Unions. The strictly enforced segregation of the sexes compelled a few students to seek their lunch outside the Union.

As regards the quality of the mid-day meal, great variations exist. We have arbitrarily defined a lunch as a meal consisting of (1) a helping of meat, egg, fish, or cheese, and (2) one helping of either potato, vegetable, or fruit, with the addition of (3) either a cooked pudding or soup. Any mid-day meal not fulfilling these standards has been called a snack. This distinction is based on custom and experience rather than nutritional standards. It has no quantitative significance and indeed many snacks provide more calories than some lunches. It is, however, a qualitative distinction of value. A snack, as we have defined it, usually is deficient in some of the essential dietary constituents, either animal protein, minerals, or vitamins. Consequently those students who only had snack meals at mid-day were dependent on extra sources of protective foods at breakfast or in the evening to balance their daily diet. The percentage having snack lunches were as follows:

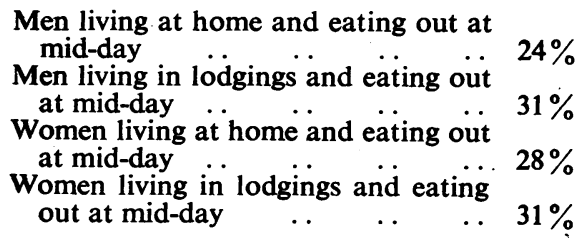

It will be seen that just under one-third of the students obtain mid-day meals which leave a leeway to be made up by extra foods of higher nutritional value at other meals. The principal cause of this failure to obtain a proper lunch is the lack of staff and facilities at the Unions to serve lunches within the limited times available for the student. The Men's Union, the Women's Union, and the King's Building Common Room are all unable to meet demands in this respect. Students have repeatedly complained to us of the poor service in the main dining rooms. The majority of those who eat snacks do so because it enables them to get some food within the time available between classes. In general snack meals are cheaper than proper lunches and a few students may be economizing in this manner. We do not believe this to be an important factor. There have been no complaints about the prices charged in Unions: only one student has specifically admitted attempting to save money on lunch.

The Evening Meal.-Two distinct types of meal are served in the evening. These may be described as dinner and high tea. They have very different origins in social evolution. Dinner, for which we have used the same arbitrary criteria as those already laid down for lunch, is generally the main meal of the day for the household; it is the meal for which there is most cooking and preparation. For several generations it has been the custom of the upper strata of society, including the professional classes, to eat the main meal of the day in the evening. This was generally satisfactory for those households with an adequate domestic staff, but as more and more housewives have failed to obtain domestic assistance and have had to cook and prepare the family meals themselves, there has been an increasing tendency to follow the custom of the labouring classes and lower middle classes and make the mid-day meal the chief meal of the day. The evening meal is then usually a high tea, a meal which, in addition to bread, butter, jam and cakes, contains a cooked dish, usually providing a single source of animal protein, e.g. meat, sausages, cheese, fish, or egg. Characteristically no puddings or vegetables are taken. We have defined high tea as an evening meal not conforming to the criteria laid down for dinner, but containing one cooked dish. These distinctions are not hard and fast; on occasions it may be difficult to decide whether a given meal is really high tea or a dinner. Any meal which did not qualify as a high tea was regarded not as an evening meal but as a snack. This classification of meals will be seen to be essentially a distinction based on the amount of cooking involved in the 
preparation of the meal, and not on its calorie content.

The figures arrived at by this means are given in Table XXIII. They represent percentages of the men and women in the four groups, and are overall figures for the week of the survey.

TABLE XXIII

Percentages of Students having Different Types of EVENING MEALS

\begin{tabular}{|c|c|c|c|c|}
\hline & \multicolumn{2}{|c|}{ Men } & \multicolumn{2}{|c|}{ Women } \\
\hline & Home & Lodgings & Home & Lodgings \\
\hline $\begin{array}{l}\text { Dinner .. } \\
\text { High tea } \\
\text { No cooked meal } \\
\text { Two meals on } \\
\text { same evening .. }\end{array}$ & $\begin{array}{l}16 \\
72 \\
12 \\
\\
6\end{array}$ & $\begin{array}{r}34 \\
67 \\
6 \\
5\end{array}$ & $\begin{array}{r}10 \\
70 \\
20 \\
2\end{array}$ & $\begin{array}{r}35 \\
55 \\
10 \\
1\end{array}$ \\
\hline
\end{tabular}

This table shows, too, that a third of the students in lodgings have dinner regularly in the evening, and only one-eighth of those at home. Also the number of women students on any particular evening who did not get a cooked meal is nearly twice as large as the number of the men, with a maximum of one student in five for those women living at home. The fact that the majority' of students had a high tea rather than a dinner would be of little significance nutritionally, if indeed they had previously had a satisfactory lunch. It is the combination of snack mid-day meal and high tea which is unsatisfactory. The numbers of students having this combination of meals on two or more of the five working days of the week was noted. Expressed as a percentage of the numbers in each group, they are given in Table XXIV. Such a combination inevitably means an inadequate consumption of vegetables during the day, and indeed is responsible for the large numbers of students, already referred to, who, throughout the week, have a small vegetable intake. Since the majority of students have no dinner at night, it becomes all the more important that arrangements should exist to enable them to get an adequate lunch.

Students in lodgings appear to have dinners at

TABLE XXIV

Percentage of Students having Snack Lunch and High TEA ON TWO OR MORE WORKING DAYS

\begin{tabular}{lllll|c|c}
\hline & & & & & Home & Lodgings \\
Men.. &.. &.. &.. &.. & 20 & 17 \\
Women &. &. & $\ldots$ &.. & 25 & 16 \\
\hline
\end{tabular}

night more often than those at home. This, no doubt, is due to the fact that most landladies do not provide mid-day meals and instead cook in the evenings. Mothers prefer to do most of their cooking at mid-day.

The figures for those having two cooked meals in the same evening, and to a large extent those having no freshly cooked meal also, are accounted for by social engagements and other functions which upset the normal pattern of meals. Only nine students (five of them living at home) had as a regular feature of the diet no cooked food in the evening.

When analysed on the basis of days of the week the most striking feature of the data was the deterioration of the evening meals at the week-ends, both in the homes and in lodgings. A decrease in the number of students having dinner and an increase in those having no cooked food in the evening was very pronounced on Saturday and Sunday. This is related to the increased number eating cooked mid-day meals on these days.

Snacks.-In addition to the three main meals, most students had one or more snacks during the day. These snacks consist of either tea or coffee and a variety of buns and cakes. Very variable amounts of food were eaten. A few students obtain a considerable proportion of the total calories of their diet from snacks. Snacks characteristically contain no cooked meat or vegetables, but a little fruit was sometimes eaten. Three times were commonly set aside for snacks. Firstly, from 11 o'clock till 12 noon, when coffee is usually drunk; secondly, from 3.30 to 4.30 p.m. when tea is taken, which is often additional to the main high tea consumed later; lastly, at 10 p.m. or later, a majority of the students had a late snack, usually tea and buns.

TABLE XXV

Percentage of Students Consuming Snacks (average OF SEVEN DAYS)

\begin{tabular}{|c|c|c|c|c|c|}
\hline & & \multicolumn{2}{|c|}{ Men } & \multicolumn{2}{|c|}{ Women } \\
\hline & & Home & Lodgings & Home & Lodgings. \\
\hline $\begin{array}{l}\text { Eleven o'clock } \\
\text { Afternoon tea } \\
\text { Late snack }\end{array}$ & $\begin{array}{l}\cdots \\
\cdots \\
\cdots\end{array}$ & $\begin{array}{l}28 \\
29 \\
70\end{array}$ & $\begin{array}{l}30 \\
31 \\
79\end{array}$ & $\begin{array}{l}33 \\
38 \\
71\end{array}$ & $\begin{array}{l}34 \\
50 \\
73\end{array}$ \\
\hline
\end{tabular}

This, no doubt, is associated with the early.hour at which the evening meal is usually eaten in Edinburgh. About one-third have coffee, usually with a cake or bun, at mid-morning. The table shows that more women than men had an afternoon tea; this is a reflection of the fact that women more often than men miss a main cooked evening meal. On 
such occasions afternoon tea had to do duty as the principal meal.

\section{Discussion and Conclusions}

1. A diet survey of 298 students under 21 years of age at Edinburgh University was carried out in December, January, and February, 1947-48. The survey was carried out by a log-book technique and each student's diet was recorded for one week.

2. There was no real shortage of calories or of energy-yielding foodstuffs. We did not find a single student who was unable to satisfy his or her appetite. While it can be stated with certainty that no student has normally gone to bed hungry, not a few have on occasions found their mid-day meals insufficient. Many students of both sexes consumed bread and potatoes in quantities far beyond the ration at the time of the survey. Had the supply of these two foods (at $63 \mathrm{oz}$. and $3 \mathrm{lb}$. per week respectively) been strictly confined to the individuals own domestic ration, many would have suffered discomfort and some real hardship.

3. Calculated recorded consumption of protein, animal protein, and fats seemed sufficient for health. This is not to say that many students would not have liked more.

4. The enforced consumption of bread made from National flour insured that intakes of vitamin $B_{1}$ were adequate. The consumption of calcium by most students was also sufficient.

5. The amount of fresh fruit and vegetables eaten was very variable and a minority of students ate small quantities of those foods. Ten per cent. of all students did not consume an average of three ounces a day of fruits and vegetables (excluding potatoes) together. This low intake of protective foods is reflected in an intake by some students of vitamin $A$ and of vitamin $C$ in amounts below acceptable physiological standards (Table III).

6. It is difficult to judge how these dietary deficiencies affect student health. It can be stated quite definitely that the quantities of vitamins consumed were always sufficient to prevent manifest clinical evidence of vitamin deficiencies in any of the students surveyed.

We investigated forty women medical students, most of whom had taken part in the survey, and showed that 10 per cent. suffered from mild anaemia (haemoglobin levels less than 90 per cent. Haldane). This finding is in no way unexpected. Indeed a proportion of women existing on diets such as have been described would be likely to have substandard haemoglobin levels.

7. The minority of students on an ill-balanced diet was evenly distributed amongst both sexes and amongst those living at home and in lodgings. The diets of those in University hostels were on the whole well-balanced.

8. From our interviews with students we would consider that a lack of elementary knowledge of human physiology was more important than a lack of money in determining bad feeding. Even at University level there is a real need for elementary health education.

9. At the start of the survey we were told that we should find many bad landladies. This has not proved so. The majority of landladies looked after their student lodgers well; not a few appeared to give food and services out of all economic proportion to the rent paid. In times of food shortages, such as the present, a great premium is put on domestic efficiency. A small minority of women failed to provide proper meals, but in our opinion the inefficient landlady is no more common than the inefficient mother.

10. Some students come from broken homes, in which one or both parents were absent, either on account of death or matrimonial separation or distant employment. The absence of either parent from the home was found usually, but not inevitably, to be reflected in inferior feeding. Irregular meals, limited cooking, and unsatisfactory diets were observed in broken homes.

11. The facilities provided at the University Unions and the Science Buildings Common Room for mid-day meals were inadequate. Poor mid-day meals were a feature of many bad diets. Large numbers of students had no proper lunch. This was in no way the fault of the catering staffs who, for the most part, were doing excellent work with insufficient accommodation and equipment.

12. The survey showed that, judged by chemical standards, the diets of the majority of the students were satisfactory. We were perhaps more impressed by the social aspects of the feeding of students. Each evening most students sup quietly at home with their families or in their lodgings. Exceptions to this are few even on Saturday nights. Undergraduate parties are not a feature of University life today in Edinburgh. We have already mentioned that four out of five men and nine out of ten women passed the week without being exposed to the socializing influence of alcohol. The garnishings of meals are absent. In Edinburgh University today a meal is a physiological action; it is rarely a social occasion. The social and economic factors which have brought about these changes are not within our present scope. We simply record that food no longer serves as a background for that essential function of a university - the exchange of ideas. 
The authors wish to express their appreciation to many members of the University staff for providing facilities for the surveys and to the students for their willing co-operation. They were assisted in the field work by Miss K. Chamberlain, B.Sc., Miss J. Davison, B.Sc., Miss N. Henry, B.Sc., and Miss M. Scott, by members of the staff of the Scientific Adviser's Division of the Ministry of Food, and by Mr.J. A. H. Lee, B.Sc., and Mr. J. G. Parish, M.B., of the University.

\section{REFERENCES}

Benedict, F. G., Miles, W. R., Roth, P., and Smith, W. (1919). "Human vitality under restricted diet." Pubn. 280, Carnegie Institute; Washington, U.S.A. Bransby, E. R., Daubney, C. G., and King, J. (1948). Brit. J. Nutrit., 2, 89.

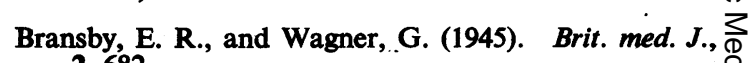
$2,682$.

Food and Nutrition Board (1948). National Research $\Rightarrow$ Council Reprint and Circular, Series No. 129.

McCance, R. A., and Widdowson, E. M. (1946). No. 235 Spec. Rep. Ser. med. Res. Coun. Lond.

"Nutritive Values of Wartime Foods." (1945.) Med. Res. Coun., War Mem. No. 14. London.

Orr, J. B. (1937). "Food, Health and Income." Macmillan. London.

Widdowson, E. M. (1936). J. Hyg. Camb., 36, $269 . \quad$ ஸे (1947). No. 257 Spec. Rep. Ser. Med. Res. Coun. Lond. , and 293 .

Youmans, J. B., Patton, E. W., and Kern, R. (1942), Amer. J. Publ. Hlth., 32, 1371. 